\title{
Evaluation of serological markers for the immunodiagnosis of acute acquired toxoplasmosis
}

\author{
LISANDRA A. SUZUKI, ROSÂNGELA J. ROCHA* and CLÁUDIO L. ROSSI \\ Department of Clinical Pathology, Faculty of Medicine and * Department of Parasitology, Insitute of Biology, \\ State University of Campinas (Unicamp), Campinas, São Paulo, Brazil
}

\begin{abstract}
The detection of specific IgM antibodies has been the most frequently used serological marker for diagnosing recent toxoplasmosis. However, the persistence of specific IgM antibodies in some patients and the use of tests with a low specificity have complicated the interpretation of serological results when toxoplasmosis is suspected. The purpose of the present study was to determine the value of newer serological techniques in the diagnosis of acute acquired toxoplasmosis. Sixty-four sera, 31 from patients with Toxoplasma gondii infection and 33 from patients with latent infection, were tested. AntiT. gondii IgA was measured by two antibody capture ELISA tests (Platelia ${ }^{\circledR}$ Toxo IgA and ETI-TOXOK A) and an automated direct ELISA (IMx ${ }^{\circledR}$ Toxo IgA); all three assays detected antibody levels compatible with a recent infection in sera from all 31 patients with acute toxoplasmosis. However, significant levels of IgA were also detected with high frequency by all three assays in sera from patients with latent infection. IgE antibodies detected by IgE immunosorbent agglutination assay (ISAGA) were present in $26(84 \%)$ of 31 patients with acute toxoplasmosis and in sera from two subjects with latent infection taken $>1$ year after the beginning of the clinical symptoms of infection. Thirty $(97 \%)$ of 31 patients with a recent $T$. gondii infection and $15(45 \%)$ of 33 subjects with latent infection had an AC/HS pattern compatible with acute toxoplasmosis. The avidity of $T$. gondii IgG was evaluated by two methods. One method was based on the titration of each serum sample and calculation of the titres, in the absence and presence of urea, in relation to a defined cut-off value. In the other method, a single serum dilution was used and the absorbances of the reactions in the presence and absence of urea were compared. The titration method was more sensitive for diagnosing recent primary infection; all 31 sera from patients with acute toxoplasmosis had avidity indices compatible with acute toxoplasmosis by the titration method, whereas with the single dilution method, sera from four patients had equivocal results. In the 33 individuals with latent infection, similar results were obtained with the two avidity methods; only one serum sample had a non-compatible avidity value with the titration method. The results obtained in the present study show that the current serological markers used for diagnosing acute acquired toxoplasmosis have significant limitations. The data suggest that determination of the avidity of $\boldsymbol{T}$. gondii-specific IgG by the titration method in patients with detectable IgM antibodies defines most accurately the stage of infection by $T$. gondii.
\end{abstract}

\section{Introduction}

Toxoplasmosis, a worldwide infection caused by the obligatory intracellular coccidian Toxoplasma gondii, is usually acquired through the ingestion of raw or undercooked meat or by contamination by oocysts present in the faeces of cats infected with the parasite.

Received 26 Nov. 1999; revised version accepted 2 June 2000.

Corresponding author: Dr C. L. Rossi.
Following multiplication within the intestinal epithelial cells, the parasites disseminate haematogenously and invade and destroy host cells of virtually every organ. T. gondii infections are generally asymptomatic or are associated with mild, non-specific clinical symptoms in immunocompetent subjects $[1,2]$.

The diagnosis of recently acquired toxoplasmosis has been done traditionally by detecting specific immunoglobulin (Ig) $\mathrm{M}$ antibodies or by demonstrating a significant increase in specific IgG antibodies, or both. 
However, the prevalence of high $\operatorname{IgG}$ antibody titres to T. gondii among normal individuals in most populations [3] and the sustained persistence, in some persons, of specific IgM antibodies [4-8] have complicated the interpretation of serological tests when toxoplasmosis is suspected. For this reason, there is an increasing demand for newer, more accurate diagnostic markers to distinguish recent from past $T$. gondii infections.

Several reports have emphasised the value of detecting specific $\operatorname{IgA}$ or $\operatorname{IgE}$ antibodies to $T$. gondii for the diagnosis of the early phase of toxoplasmosis [9-16]. However, the persistence of such antibodies following an acute infection is still controversial. The fixation of tachyzoite forms of $T$. gondii with either formalin or acetone causes a significant difference in their affinity for antibodies from patients with recently acquired toxoplasmosis compared with subjects with past infection. The differential agglutination (AC/HS) test compares antibody titres obtained with formalin- and acetone-fixed tachyzoite forms of $T$. gondii [16-19]. High titres in the AC test are associated with a recently acquired infection, whereas high titres in the HS test are associated with past infection [16, 19]. Following the observation that antibody avidity gradually increases after exposure to an immunogen [20,21], several reports have shown that the low avidity of $\mathrm{IgG}$ antibody can be used as a marker for diagnosing recent primary infections, including toxoplasmosis [22-26].

The purpose of the present study was to assess the usefulness of newer serological markers, such as the IgA ELISA, IgE immunosorbent agglutination assay (ISAGA), avidity of Toxoplasma-specific IgG and differential agglutination (AC/HS) test in the diagnosis of acute acquired toxoplasmosis.

\section{Materials and methods}

\section{Serological tests}

Anti-T. gondii IgA was measured by three commercial ELISA techniques, IMx ${ }^{\circledR}$ Toxo IgA (Abbot Laboratories, Chicago, IL, USA), Platelia ${ }^{\circledR}$ Toxo IgA (Sanofi Diagnostics, Marnes la Coquette, France) and ETITOXOK-A reverse (DiaSorin Biomédica, Sallugia, Italy). The three ELISA techniques were performed according to the manufacturers' instructions. The $\mathrm{IMx}^{\circledR}$ Toxo $\operatorname{IgA}$, an automated microparticle direct enzyme immunoassay, was performed on an IMx Analyzer. The IMx assay indexes the patient sample rate to an IMx Toxo IgA index calibrator (anti- $T$. gondii IgA antibody) rate, according to the formula: index $=$ sample rate/index calibrator rate. IMx Toxo IgA indices $\geqslant 0.600$ and $<0.500$ were regarded as positive and negative, respectively; indices of $0.500-$ 0.599 were considered as equivocal.
For assays performed by the Platelia IgA method, each run included positive (R4b) and negative control sera, plus a cut-off control serum (R4a), in duplicate. Sera with an optical density (OD) greater than or equal to the mean OD for R4a serum were considered positive. Sera with an OD less than the mean $\mathrm{R} 4 \mathrm{a}$ OD $\times 0.8$ were considered negative; sera with values between the mean $\mathrm{R} 4 \mathrm{a}$ OD $\times 0.8$ and the mean $\mathrm{R} 4 \mathrm{a}$ OD were considered doubtful. Positive results were expressed by calculating the fixation index from the formula: serum fixation index $=$ (sample OD - mean $\mathrm{R} 4 \mathrm{a}$ OD/R4b OD - mean R4a OD) $\times 10$. Fixation indices between 0 and 2 corresponded to a borderline positive serum, whereas indices $>2$ probably indicated a recent infection by $T$. gondii.

For assays performed by the ETI-TOXOK-A method, serum standards ranging from 0 to 160 arbitrary units $(\mathrm{AU}) \mathrm{ml}$ were included in each assay. All sera were tested in duplicate and the resulting mean absorbance was then converted into $\mathrm{AU} / \mathrm{ml}$ with an appropriate standard curve. According to the manufacturer's instructions, most patients with acute toxoplasmosis have specific IgA levels $\geqslant 40 \mathrm{AU} / \mathrm{ml}$. Levels of $10-$ $40 \mathrm{AU} / \mathrm{ml}$ cannot be regarded as negative and their importance must be interpreted in association with specific IgM and IgG determinations; levels $<10$ $\mathrm{AU} / \mathrm{ml}$ are regarded as negative.

The IgE-ISAGA was performed as described by Ashburn et al. [27], with minor modifications. Briefly, each well of a U-shaped polystyrene microtitration plate (Corning, New York, NY, USA) was coated with $100 \mu \mathrm{l}$ of anti-human IgE mouse monoclonal antibody (MAb) (Sigma) diluted to $2.4 \mu \mathrm{g} / \mathrm{ml}$ in $0.1 \mathrm{M}$ carbonate-bicarbonate buffer, $\mathrm{pH}$ 9.5. Each serum sample was diluted 1 in 100 in phosphate-buffered saline (PBS) containing bovine serum albumin (BSA) $0.1 \%$ and $100 \mu \mathrm{l}$ were added to each of three adjacent wells. Positive and negative controls were included in each plate. After incubation for $2 \mathrm{~h}$ at $37^{\circ} \mathrm{C}$, the plates were washed with PBS plus Tween $200.1 \%$ and then with PBS alone. A suspension of formalin-fixed tachyzoites was diluted in alkaline buffer $(\mathrm{pH}$ 8.7) to 1.25 $\times 10^{7}$ parasites $/ \mathrm{ml}$ and 100,150 and $200 \mu \mathrm{l}$ were added to the three wells corresponding to the same sera described above. After incubation, the results were read visually against a black background with lateral lighting. A complete tachyzoite carpet at the bottom of the well was assigned a value of 4 and a sedimentation pattern forming a discrete button was assigned a value of 0 . Intermediate results which represented c. 25, 50 and $75 \%$ agglutination were scored as 1, 2 and 3 , respectively. The sum of the values of the three wells used for each serum sample can produce a minimum and a maximum value of 0 and 12 , respectively. IgE ISAGA results $\leqslant 2$ were considered to be negative, 3-4 equivocal and $\geqslant 5$ positive.

The AC/HS test was done and interpreted as described 
by Dannemann et al. [19]. Briefly, formalin-fixed tachyzoites (HS antigen) and acetone-fixed tachyzoites (AC antigen) were resuspended in alkaline buffer $(\mathrm{pH}$ 8.7) containing BSA $1 \%$ at a concentration of $3 \times 10^{7}$ parasites $/ \mathrm{ml}$. A $50-\mu 1$ aliquot of antigen preparation (HS or AC antigen) was added to $50 \mu \mathrm{l}$ of two-fold dilutions of sera in microtitration plates. Sera were diluted in PBS, pH 7.2 containing $0.2 \mathrm{M} 2$ mercaptoethanol. The first serum dilution for the HS antigen ( 1 in 2000) was assigned an antibody titre of $100 \mathrm{IU} / \mathrm{ml}$. The first serum dilution for the AC antigen was 1 in 100 ; to which an antibody titre of $50 \mathrm{IU} / \mathrm{ml}$ was assigned. The plates were read after overnight incubation at room temperature.

The avidity of $T$. gondii IgG antibodies was measured by two ELISA techniques, one with the Falcon Assay Screening Test System (FAST ${ }^{\circledR}$ - ELISA) and the other with a commercial ELISA kit for detecting specific IgG antibodies to T. gondii (Platelia ${ }^{\circledR}$ Toxo IgG, Sanofi Diagnositics Pasteur, France). The IgG avidity-FASTELISA was performed as described elsewhere [26]. Briefly, the FAST-ELISA system uses polystyrene beads on sticks moulded to the lid of a microtitration plate. For the assay, the beads were coated with a soluble antigen from sonicated $T$. gondii. A single dilution (1 in 21) of the serum samples being tested, PBS containing $6 \mathrm{M}$ urea (or PBS as control), conjugate (goat anti-human IgG labelled with peroxidase) and the substrate system $\left(3,3^{\prime}, 5,5^{\prime}\right.$-tetramethylbenzidine $\left./ \mathrm{H}_{2} \mathrm{O}_{2}\right)$ were placed in standard microtitration plates. The sensitised beads were exposed to the reagents by immersion, after appropriate washing. All serum samples were run twice in triplicate. The avidity index was calculated as the mean absorbance of reactions in which the beads were exposed to urea divided by the mean absorbance of reactions in which the beads were not exposed to urea, expressed as a percentage. Avidity indices $\leqslant 40 \%$ and $\geqslant 58 \%$ are considered as indicative of recent and long-term infections, respectively. The IgG avidity test with the Platelia Toxo IgG was performed as described by Jenum et al. [25]. Briefly, each serum sample was analysed in two four-fold range dilutions in two rows of the ELISA plate; the first serum dilution was 1 in 50 in one of the rows (row A) and 1 in 200 in the second row (row B). After incubation for $1 \mathrm{~h}$ at $37^{\circ} \mathrm{C}$, row $\mathrm{A}$ was washed three times with PBS-Tween containing $6 \mathrm{M}$ urea, whereas row B (control row) was washed three times with the washing solution (no urea) that accompanied the kit. During each wash, the microtitration plate was shaken vigorously for $5 \mathrm{~min}$. The subsequent steps of the reaction, including incubation with conjugate, washing, incubation with substrate and the addition of stopping solution were performed as recommended by the manufacturer. The optical density (OD) of each well was read in a microtitration plate reader (Spectra SLT Labinstruments, Salzburg, Austria) at $492 \mathrm{~nm}$, with $620 \mathrm{~nm}$ used as the reference wavelength. For each serum sample, two end-point titres, one for row A (washed with urea after antigen-antibody reaction) and one for row B (washed without urea), were calculated as the dilution that gave an OD of 0.1 on a semilogarithmic plot (OD, arithmetic scale; dilution, logarithmic scale) using the formula: titre $=$ dilution $_{\mathrm{x}}$ $\times 10^{\mathrm{a}}$, where dilution ${ }_{\mathrm{x}}$ is the highest dilution giving an $\mathrm{OD}>0.1$ and $\mathrm{a}$ is equal to $\log 4 \times\left(\mathrm{OD}_{\mathrm{x}}-\right.$ $0.1) /\left(O_{x}-O D_{y}\right)$ where 4 is the dilution factor, $\mathrm{OD}_{\mathrm{x}}$ is the $\mathrm{OD}$ at dilution $\mathrm{x}, 0.1$ is the cut-off $\mathrm{OD}$, and $\mathrm{OD}_{\mathrm{y}}$ is the $\mathrm{OD}$ at the next higher dilution from dilution $_{\mathrm{x}}$. The $\mathrm{IgG}$ avidity was calculated with the formula: avidity $=($ titre in row A/titre in row $\mathrm{B}) \times 100$. Avidity indices $\leqslant 26.5 \%$ were associated with a recent T. gondii infection $(<20$ weeks earlier), whereas indices $\geqslant 30.6$ were associated with a latent infection.

\section{Patients and serum samples}

The serological tests were evaluated by testing 31 sera from patients (15 males, 16 females; mean age 23 years, range, 6-49 years) with a recent primary $T$. gondii infection and 33 sera from patients $(3$ males, 30 females; mean age 29 years, range 15-45 years) with latent $T$. gondii infection. All cases attended the University Hospital of the State University of Campinas, São Paulo, Brazil. Patients were diagnosed as having acute toxoplasmosis based on serodiagnostic criteria: detectable IgM antibodies by IIF and ELISA tests plus either seroconversion or $a \geqslant 4$-fold rise in the titre of anti- $T$. gondii specific $\operatorname{IgG}$ by immunofluorescent assay. All 31 patients in this group had clinical symptoms compatible with acute toxoplasmosis and sera were collected in the first 3 months after the onset of clinical symptoms. All 33 patients with pre-existing immunity to $T$. gondii had a well-documented history of acute toxoplasmosis at least 1 year before blood collection, and four had persistent specific IgM antibodies to $T$. gondii by ELISA.

\section{Results}

The serological data obtained from sera of patients with acute toxoplasmosis and from patients with latent infection with $T$. gondii are shown in Tables 1 and 2, respectively.

All 31 patients with acute toxoplasmosis had specific IgA antibody levels compatible with a recent $T$. gondii infection by the IMx, Platelia and ETI-TOXOK-A assays. According to the manufacturer's instructions for the ETI-TOXOK-A assay, most patients with acute toxoplasmosis have specific IgA levels $>40 \mathrm{AU} / \mathrm{ml}$. Only one case (patient A7) had a T. gondii-specific IgA antibody level $<40 \mathrm{AU} / \mathrm{ml}(20.1 \mathrm{AU} / \mathrm{ml})$ with this assay. On the other hand, in the 33 patients with latent infection, IgA antibody levels compatible with recent toxoplasmosis were detected in six cases by the IMx assay (patients L1-L3, L6, L31 and L33) and in five cases with the Platelia and ETI-TOXOK-A methods 
Table 1. T. gondii serology in patients with acute toxoplasmosis

\begin{tabular}{|c|c|c|c|c|c|c|c|c|c|c|}
\hline \multirow[b]{2}{*}{ Patient no. } & \multirow[b]{2}{*}{ Time (months) } & \multicolumn{2}{|c|}{ IgM } & \multicolumn{3}{|c|}{$\operatorname{Ig} \mathrm{A}$} & \multirow[b]{2}{*}{$\begin{array}{l}\text { IgE-ISAGA } \\
\text { (score) }\end{array}$} & \multirow[b]{2}{*}{$\begin{array}{l}\text { AC/HS test }(\mathrm{IU} / \mathrm{ml}) \\
\text { (A/NA pattern) }\end{array}$} & \multicolumn{2}{|c|}{ Avidity test } \\
\hline & & IIF & ELISA & $\begin{array}{c}\text { IMx } \\
\text { (index) }\end{array}$ & $\begin{array}{c}\text { Platelia } \\
\text { (index) }\end{array}$ & $\begin{array}{c}\begin{array}{c}\text { ETI-TOXOK } \\
(\mathrm{AU} / \mathrm{ml})\end{array} \\
\end{array}$ & & & $\begin{array}{c}\text { FAST-ELISA } \\
\text { (index) }\end{array}$ & $\begin{array}{r}\text { Platelia } \\
\text { (index) }\end{array}$ \\
\hline $\mathrm{A} 1$ & 1 & 2048 & $\mathrm{R}$ & 4.9 & 36.7 & 264.7 & 12 & $400 /<100(\mathrm{~A})$ & 16 & 9.4 \\
\hline A2 & 1 & 2048 & $\mathrm{R}$ & 3.1 & 44.0 & 250.1 & 12 & $>1600 / 1600(\mathrm{~A})$ & 26 & 23.6 \\
\hline A3 & 1 & 4096 & $\mathrm{R}$ & 3.2 & 48.4 & 291.9 & 12 & $>1600 / 800(\mathrm{~A})$ & 19 & 3.1 \\
\hline A4 & 1 & 128 & $\mathrm{R}$ & 3.1 & 30.2 & 209.4 & 2 & $<50 / 100$ (NA) & 23 & 18 \\
\hline A5 & 1 & 4096 & $\mathrm{R}$ & 4.1 & 39.1 & 236.7 & 12 & 400/200 (A) & 20 & 8.7 \\
\hline A6 & 1.5 & 8192 & $\mathrm{R}$ & 3.0 & 40.8 & 188.1 & 12 & $1600 / 800(\mathrm{~A})$ & 31 & 3.1 \\
\hline A7 & 2 & 2048 & $\mathrm{R}$ & 1.6 & 5.0 & 20.1 & 0 & $1600 / 400(\mathrm{~A})$ & 25 & 11.6 \\
\hline A8 & 1 & 512 & $\mathrm{R}$ & 2.7 & 25.8 & 219.4 & 12 & $1600 / 800(\mathrm{~A})$ & 24 & 6.3 \\
\hline A9 & 1 & 8192 & $\mathrm{R}$ & 4.5 & 40.1 & 255.7 & 12 & $>1600 / 200(\mathrm{~A})$ & 11 & 3 \\
\hline A10 & 1 & 4096 & $\mathrm{R}$ & 4.2 & 42.1 & 267.6 & 12 & $800 / 400$ (A) & 28 & 7.3 \\
\hline A11 & 2 & 2048 & $\mathrm{R}$ & 1.8 & 32.0 & 194.3 & 12 & $1600 / 800(\mathrm{~A})$ & 30 & 3.1 \\
\hline A12 & 1 & 512 & $\mathrm{R}$ & 2.6 & 18.6 & 177.4 & 12 & $100 /<100$ (A) & 2 & 17.3 \\
\hline A13 & 1.5 & 1024 & $\mathrm{R}$ & 4.9 & 36.2 & 261.5 & 11 & $1600 / 1600$ (A) & 27 & 6.8 \\
\hline A14 & 1 & 1024 & $\mathrm{R}$ & 1.9 & 32.1 & 255.1 & 11 & $1600 / 1600$ (A) & 30 & 17.5 \\
\hline A15 & 2 & 2048 & $\mathrm{R}$ & 5.4 & 45.0 & 273.8 & 12 & $>1600 / 1600(\mathrm{~A})$ & 40 & 1.7 \\
\hline A16 & 2 & 2048 & $\mathrm{R}$ & 4.1 & 46.7 & 259.8 & 12 & $>1600 / 3200(\mathrm{~A})$ & 37 & 3.3 \\
\hline A17 & 1 & 2048 & $\mathrm{R}$ & 4.8 & 44.3 & 276.8 & 12 & $400 / 400(\mathrm{~A})$ & 25 & 7 \\
\hline A18 & 1 & 512 & $\mathrm{R}$ & 4.8 & 38.2 & 275.9 & 2 & $>1600 / 400(\mathrm{~A})$ & 17 & 6.1 \\
\hline A19 & 3 & 4096 & $\mathrm{R}$ & 2.2 & 46.0 & 279.4 & 12 & $>1600 />3200(\mathrm{~A})$ & 42 & 0.9 \\
\hline A20 & 1.5 & 8192 & $\mathrm{R}$ & 3.0 & 38.5 & 218.4 & 12 & $>1600 / 800(\mathrm{~A})$ & 37 & 2.6 \\
\hline A21 & 1.5 & 512 & $\mathrm{R}$ & 2.8 & 22.4 & 168.3 & 12 & $400 / 800$ (A) & 4 & 3.2 \\
\hline A22 & 1 & 8192 & $\mathrm{R}$ & 2.9 & 41.2 & 196.9 & 12 & $>1600 / 800(\mathrm{~A})$ & 13 & 5.8 \\
\hline A23 & 1 & 1024 & $\mathrm{R}$ & 4.8 & 37.6 & 234.9 & 12 & $1600 / 1600(\mathrm{~A})$ & 26 & 20 \\
\hline A24 & 1 & 4096 & $\mathrm{R}$ & 2.2 & 49.6 & 262.4 & 12 & $>1600 / 800(\mathrm{~A})$ & 25 & 7.9 \\
\hline A25 & 1 & 1024 & $\mathrm{R}$ & 1.8 & 25.8 & 220.8 & 3 & $>1600 / 800(\mathrm{~A})$ & 36 & 1.2 \\
\hline A26 & 1 & 8192 & $\mathrm{R}$ & 4.8 & 45.4 & 261.4 & 7 & $>1600 / 1600(\mathrm{~A})$ & 23 & 10 \\
\hline A27 & 1 & 2048 & $\mathrm{R}$ & 1.3 & 40.2 & 263.6 & 12 & $>1600 / 1600(\mathrm{~A})$ & 18 & 0.6 \\
\hline A28 & 3 & 1024 & $\mathrm{R}$ & 1.4 & 42.5 & 264.1 & 10 & $>1600 / 1600(\mathrm{~A})$ & 45 & 3.3 \\
\hline A29 & 1 & 4096 & $\mathrm{R}$ & 2.4 & 34.6 & 201.6 & 12 & $>1600 / 800(\mathrm{~A})$ & 22 & 6.3 \\
\hline A30 & 3 & 512 & $\mathrm{R}$ & 1.3 & 35.0 & 237.3 & 12 & $>1600 />3200(\mathrm{~A})$ & 45 & 8.2 \\
\hline A31 & 3 & 1024 & $\mathrm{R}$ & 1.6 & 54.9 & 189.9 & 0 & $>1600 / 800(\mathrm{~A})$ & 44 & 5 \\
\hline
\end{tabular}

Time $=$ months from the onset of clinical symptoms to the time of blood sampling.

Significant antibody results: IgM-IIF $\geqslant 32$; IgM-ELISA $=$ reactive (R); IgA-ELISA IMx index $\geqslant 0.6$; IgA-ELISA Platelia index $>2$; IgA-ELISA ETI-TOXOK $>10$ AU/ml; IgE-ISAGA $\geqslant 5$; AC/HS test: A, compatible with an acute pattern, NA, not compatible with an acute pattern. FAST-ELISA avidity indices $\leqslant 40 \%$ and $\geqslant 58 \%$ are indicative of recent and long-term $T$. gondii infections, respectively. Platelia avidity indices $\leqslant 26.5 \%$ and $\geqslant 30.6 \%$ are indicative of recent and long-term T. gondii infections, respectively. 
Table 2. T. gondii serology in patients with latent toxoplasmosis

\begin{tabular}{|c|c|c|c|c|c|c|c|c|c|c|}
\hline \multirow[b]{2}{*}{ Patient no. } & \multirow[b]{2}{*}{ Time (months) } & \multicolumn{2}{|c|}{ IgM } & \multicolumn{3}{|c|}{ IgA } & \multirow[b]{2}{*}{$\begin{array}{l}\text { IgE-ISAGA } \\
\text { (score) }\end{array}$} & \multirow[b]{2}{*}{$\begin{array}{l}\mathrm{AC} / \mathrm{HS} \text { test }(\mathrm{IU} / \mathrm{ml}) \\
(\mathrm{A} / \mathrm{NA} \text { pattern })\end{array}$} & \multicolumn{2}{|c|}{ Avidity test } \\
\hline & & $\begin{array}{l}\mathrm{IIF} \\
\text { (titre) }\end{array}$ & $\begin{array}{l}\text { ELISA } \\
(\mathrm{R} / \mathrm{NR})\end{array}$ & $\begin{array}{l}\text { IMx } \\
\text { (index) }\end{array}$ & $\begin{array}{l}\text { Platelia } \\
\text { (index) }\end{array}$ & $\begin{array}{l}\text { ETI-TOXOK } \\
(\mathrm{AU} / \mathrm{ml})\end{array}$ & & & $\begin{array}{l}\text { FAST-ELISA } \\
\text { (index) }\end{array}$ & $\begin{array}{l}\text { Platelia } \\
\text { (index) }\end{array}$ \\
\hline L1 & 20 & $<16$ & NR & 3.90 & 28.2 & 160 & 0 & $1600 / 1600$ (A) & 83 & 95.0 \\
\hline $\mathrm{L} 2$ & 13 & $<16$ & $\mathrm{R}$ & 3.00 & 38.0 & 180 & 11 & $>1600 />3200(\mathrm{~A})$ & 85 & 74.0 \\
\hline L3 & 14 & $<16$ & $\mathrm{R}$ & 1.15 & 8.3 & 26 & 12 & $1600 / 1600$ (A) & 87 & 68.0 \\
\hline L4 & 72 & 16 & $\mathrm{R}$ & 0.54 & NS & 8 & 2 & $1600 / 200(\mathrm{~A})$ & 86 & 55.0 \\
\hline L5 & 24 & $<16$ & NR & 0.17 & NS & 1 & 0 & $50 / 400$ (NA) & 68 & 63.0 \\
\hline L6 & 16 & $<16$ & $\mathrm{R}$ & 2.43 & 5.1 & 13 & 0 & $1600 / 3200(\mathrm{~A})$ & 87 & 99.0 \\
\hline L7 & 72 & $<16$ & NR & 0.39 & NS & 4 & 0 & $100 / 800$ (NA) & 88 & 73.0 \\
\hline L8 & 24 & $<16$ & NR & 0.09 & NS & 1 & 0 & $<50 / 100$ (NA) & 67 & 87.0 \\
\hline L9 & 26 & $<16$ & NR & 0.43 & NS & 3.5 & 0 & $50 / 400$ (NA) & 78 & 55.0 \\
\hline L10 & 18 & $<16$ & NR & 0.51 & NS & 3.5 & 0 & $1600 / 400(\mathrm{~A})$ & 81 & 60.5 \\
\hline L11 & 30 & $<16$ & NR & 0.44 & NS & 1.5 & 0 & $50 / 800$ (NA) & 73 & 79.4 \\
\hline L12 & 26 & $<16$ & NR & 0.17 & NS & 1 & 0 & $<50 / 200(\mathrm{NA})$ & 64 & 63.6 \\
\hline L13 & 25 & $<16$ & NR & 0.06 & NS & 1.5 & 0 & $<50 / 200$ (NA) & 77 & 56.0 \\
\hline L14 & 27 & $<16$ & NR & 0.52 & NS & 1 & 0 & $50 / 800$ (NA) & 85 & 80.0 \\
\hline L15 & 28 & $<16$ & NR & 0.10 & NS & 1 & 0 & $<50 / 200$ (NA) & 95 & 84.0 \\
\hline L16 & 25 & $<16$ & NR & 0.11 & NS & 1 & 0 & $<50 / 400$ (NA) & 71 & 73.0 \\
\hline L17 & 24 & $<16$ & NR & 0.52 & NS & 2 & 0 & $<50 / 800$ (NA) & 63 & 55.6 \\
\hline L18 & 26 & $<16$ & NR & 0.08 & NS & 1 & 0 & $<50 / 400$ (NA) & 76 & 71.0 \\
\hline L19 & 26 & $<16$ & NR & 0.07 & NS & 1 & 0 & $<50 / 400$ (NA) & 81 & 99.0 \\
\hline L20 & 28 & $<16$ & NR & 0.19 & NS & 1 & 0 & $<50 / 800(\mathrm{NA})$ & 79 & 58.3 \\
\hline L21 & 27 & $<16$ & NR & 0.13 & NS & 2 & 0 & $<50 / 800$ (NA) & 68 & 61.5 \\
\hline L22 & 25 & $<16$ & NR & 0.16 & NS & 2 & 0 & $>1600 / 400(\mathrm{~A})$ & 59 & 48.0 \\
\hline L23 & 19 & $<16$ & NR & 0.07 & NS & 1 & 0 & $<50 / 800$ (NA) & 78 & 43.0 \\
\hline L24 & 20 & $<16$ & NR & 0.1 & NS & 1 & 0 & $<50 / 800$ (NA) & 65 & 90.0 \\
\hline L25 & 21 & $<16$ & NR & 0.12 & NS & 1 & 0 & $>1600 / 400(\mathrm{~A})$ & 67 & 68.0 \\
\hline L26 & 20 & $<16$ & NR & 0.07 & NS & 1 & 0 & $>1600 / 400(\mathrm{~A})$ & 87 & 99.0 \\
\hline L27 & 21 & $<16$ & NR & 0.22 & NS & 0.5 & 0 & $>1600 / 800$ (A) & 78 & 50.0 \\
\hline L28 & 22 & $<16$ & NR & 0.22 & NS & 0.5 & 0 & $>1600 / 400(\mathrm{~A})$ & 81 & 58.0 \\
\hline L29 & 18 & $<16$ & NR & 0.16 & NS & 1.7 & 0 & $>1600 / 800(\mathrm{~A})$ & 69 & 63.0 \\
\hline L30 & 19 & $<16$ & NR & 0.16 & NS & 0.5 & 2 & $>1600 / 800(\mathrm{~A})$ & 74 & 58.3 \\
\hline L31 & 36 & $<16$ & NR & 1.42 & 7.4 & 26.5 & 2 & $400 / 3200$ (NA) & 99 & 71.0 \\
\hline L32 & 36 & $<16$ & NR & 0.30 & 1.0 & 4 & 2 & $>1600 / 800(\mathrm{~A})$ & 99 & 57.0 \\
\hline L33 & 38 & $<16$ & NR & 1.08 & 0.6 & 4 & 2 & $>1600 / 800(\mathrm{~A})$ & 95 & 25.0 \\
\hline
\end{tabular}

NR, non-reactive; NS, non-significant.

Time $=$ months from the onset of clinical symptoms to the time of blood sampling.

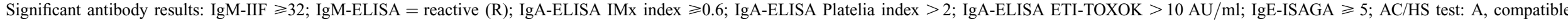
with an acute pattern, NA, not compatible with an acute pattern. FAST-ELISA avidity indices $\leqslant 40 \%$ and $\geqslant 58 \%$ are indicative of recent and long-term $T$. gondii infections, respectively. Platelia avidity indices $\leqslant 26.5 \%$ and $\geqslant 30.6 \%$ are indicative of recent and long-term $T$. gondii infections, respectively. 
(patients L1-L3, L6, L31). Four equivocal results were obtained with the IMx method (patients L4, L10, L14 and L17) and two borderline positive results were obtained with the Platelia assay (cases L32 and L33). In total, five patients (L1-L3, L6, L31) had IgA detected by all three assays which defined acute rather than latent infection; interestingly, three of these patients had significant serum levels of specific IgM antibodies detected by ELISA (L2, L3 and L6).

IgE ISAGA results compatible with a recent $T$. gondii infection (score $\geqslant 5$ ) were observed in $26(84 \%)$ of the 31 patients with acute toxoplasmosis; antibody titres ranged from 7 to 12 . Of the five patients with noncompatible results, four had a negative IgE ISAGA result (patients A4, A7, A18 and A31) and one had a doubtful result (patient A25). IgE ISAGA results defining latent toxoplasmosis (score $\leqslant 2$, were observed in $31(94 \%)$ of the 33 patients with latent infection. Both the patients (L2 and L3) with incompatible results had IgE ISAGA values $\geqslant 11$ and positive ELISA results for specific IgM antibodies.

An acute AC/HS pattern was seen in 30 (97\%) of 31 patients with acute toxoplasmosis; only one patient (A4) had an AC/HS titre <50/100. However, AC/HS titres compatible with an acute pattern were observed in $15(45 \%)$ of 33 persons with latent infection (L1L4, L6, L10, L22, L25-L30, L32 and L33); four of these had detectable $T$. gondii-specific IgM antibodies by ELISA (L2-L4 and L6).

The FAST-ELISA avidity indices for 31 sera from patients with acute toxoplasmosis ranged from 2 to $45 \%$ (mean index $=26.2 \%$ ), whereas for sera from the 33 subjects with latent infection, the indices ranged from 59 to $99 \%$ (mean index $=78.6 \%$ ). FASTELISA avidity indices $\leqslant 40 \%$ and $\geqslant 58 \%$ are considered indicative of recent and long-term infection, respectively. In this study, $27(87 \%)$ of 31 patients with acute toxoplasmosis had FAST-ELISA avidity indices compatible with a recent infection. The remaining four patients (A19, A28, A30 and A31) had inconclusive avidity indices (42-45\%). All 33 persons with latent infection had compatible FASTELISA avidity indices $(>58 \%)$. The ELISA Platelia avidity indices for 31 sera from patients with acute toxoplasmosis ranged from 0.6 to $23.6 \%$ (mean index $=7.5 \%$ ), whereas for sera from the 33 persons with latent infection, the indices ranged from 25 to $99 \%$ (mean index $=67.9 \%$ ). ELISA Platelia avidity indices $\leqslant 26.5 \%$ and $\geqslant 30.6 \%$ are considered indicative of a recent (infected $<20$ weeks earlier) and latent infection, respectively.

All 31 patients with acute toxoplasmosis had ELISA Platelia avidity indices compatible with a recent infection whilst only one patient with latent infection had an avidity index compatible with a recent infection (L33).

\section{Discussion}

The diagnosis of a recently acquired $T$. gondii infection is usually based on the detection of specific IgM antibodies, seroconversion or a four-fold or greater rise in the titre of $T$. gondii-specific $\mathrm{IgG}$ antibodies. As seroconversion and a rise in IgG titres are seldom demonstrable, the detection of $T$. gondii-specific IgM antibodies has been the most frequently used serological marker for diagnosing acute infection. In many countries, the diagnosis of acute toxoplasmosis is based on the detection of specific IgM antibodies in a single serum sample. The use of tests with a low specificity and the persistence, in some patients, of specific IgM antibodies for a long time have led to the misdiagnosis of acute toxoplasmosis and unnecessary concern, especially with regard to pregnant women. Liesenfeld et al. [28] evaluated the accuracy of the Platelia Toxo IgM test in 575 sera obtained during an outbreak of toxoplasmosis in Canada. When compared with results obtained with a reference IgM ELISA [16, 29], the Platelia test had a sensitivity of $99.4 \%$, but a specificity of only $49.2 \%$. Of the 153 sera positive in the Platelia test and negative in the reference ELISA, 71 (46.4\%) were negative in the Sabin-Feldman dye test. Various confirmatory tests have been proposed to distinguish recent from past toxoplasmosis, including $\operatorname{IgA}$ and $\operatorname{IgE}$ antibody tests, the differential agglutination (AC/HS) test and $\operatorname{IgG}$ avidity tests.

T. gondii-specific IgA and $\operatorname{IgE}$ antibodies have been measured by ELISA and ISAGA in sera from patients with toxoplasmosis. In the present study, specific IgA antibodies were detected by two antibody capture ELISA tests (Platelia Toxo IgA and ETI-TOXOK-A) and an automated direct ELISA (IMX Toxo IgA). A surface protein of $T$. gondii with a mol. wt of 30000 (P30) has been shown by several immunological studies to be a major antigen of the parasite $[30,31]$. In antibody capture assays, a horseradish peroxidaseconjugated anti-P30 MAb is used as the enzyme tracer. Several reports have shown that anti- $T$. gondii $\operatorname{IgA}$ antibodies are frequently detected in acute acquired toxoplasmosis [9-11,13,15]. Decoster et al. [10] showed that during toxoplasmosis an intense $\operatorname{IgA}$ antibody response is directed against the P30 antigen of $T$. gondii with specific anti-P30 antibodies detected in sera of all patients studied during the acute phase of acquired toxoplasmosis. In a previous study, sera from 51 patients with acute toxoplasmosis were screened for specific IgA antibodies with the ETI-TOXOK-A kit; 50 $(99 \%)$ of the 51 sera tested had significant levels of specific $\operatorname{IgA}$ antibodies [15].

The persistence of $T$. gondii-specific $\operatorname{IgA}$ antibodies following acute infection is still controversial. Turunen et al. [32] used a four-layer ELISA to evaluate specific antibodies during toxoplasmosis and showed that the $\operatorname{IgA}$ antibody response was slower than the $\operatorname{IgM}$ response. This suggested that the detection of $\operatorname{IgA}$ 
could improve the laboratory diagnosis in cases where IgM antibodies had already disappeared and where no further increase in $\mathrm{IgG}$ antibodies could be detected. Decoster et al. [10] did not detect anti-P30 IgA antibodies in sera from patients with chronic toxoplasmosis, whereas in some sera significant levels of $T$. gondii-specific IgM antibodies were detected $>1$ year after the infection.

Gorgievski-Hrisoho et al. [33] evaluated commercial $T$. gondii IgA kits and showed that the Platelia IgA kit was more sensitive than the TOXOK-A and Toxo IgA ELISA (Eurogenetics SA, Belgium) kits for diagnosing recent $T$. gondii infection. Positive Platelia IgA results were found in all patients with an evolving immune response, suggestive of recent toxoplasmosis. However, kinetic studies revealed that in most cases the decline in the reactivity of $\operatorname{IgA}$ antibodies detected by the Platelia test was slower than for IgM antibodies detected by ELISA. Bertozzi et al. [8] reported the detection of specific IgA antibodies by the ETITOXOK-A kit in sequential sera from a patient exhibiting significant levels of $T$. gondii-specific IgM antibodies for 7 years after the onset of the clinical symptoms of toxoplasmosis. Although shorter persistence of specific IgA antibodies was observed, significant levels $(>10 \mathrm{AU} / \mathrm{ml})$ of $\operatorname{IgA}$ were detected for 2 years after the onset of clinical symptoms. As defined by the manufacturer of the ETI-TOXOK-A kit, most patients with acute toxoplasmosis have $\operatorname{IgA}$ antibody levels $>40 \mathrm{AU} / \mathrm{ml}$. At this cut-off value, significant levels of IgA were detected for 1 year after the beginning of clinical manifestations. IgA levels $\leqslant 40 \mathrm{AU} / \mathrm{ml}$ with the ETI-TOXOK-A kit do not exclude a recent infection, as in some patients such levels can be reached very soon after infection with $T$. gondii [34]. Decoster et al. [35] reported no significant differences in the sensitivities and specificities of the Platelia IgA and the IMx Toxo IgA kits for the diagnosis of acquired toxoplasmosis. Nevertheless, the Platelia $\operatorname{IgA}$ test was more efficient in establishing the date of infection because anti-P30 IgA antibodies disappeared earlier than IgA antibodies detected by the IMx Toxo IgA kit.

The present study confirmed that anti-T. gondii IgA antibodies are detected with high frequency in patients with toxoplasmosis. The IMx, Platelia and ETITOXOK-A kits detected antibody levels compatible with recent toxoplasmosis in sera from all 31 patients with acute infection. On the other hand, the analysis of sera from 33 individuals with a latent infection revealed that significant levels of specific $\operatorname{IgA}$ antibodies may be detected with a high frequency by the three kits for prolonged periods after infection. In some patients with latent infection specific IgA antibodies were detected in the absence of specific $\operatorname{IgM}$ antibodies.

Specific IgE antibodies appear early in $T$. gondii infection, almost simultaneously with $\operatorname{IgM}$ and $\operatorname{IgA}$ antibodies [12]. Significant levels of specific IgE antibodies have been demonstrated in $63-100 \%$ of patients with toxoplasmosis of documented onset $[12,14,16]$. Pinon et al. [12] reported that the IgEISAGA was positive in sera from $25(86 \%)$ of 29 women who seroconverted during gestation or had specific IgA and IgM antibodies. Specific IgE was present early in infection, simultaneous with IgM antibodies, but slightly preceding the presence of IgA antibodies. In sequential sera from 23 patients with toxoplasmosis, IgE antibodies never persisted for longer than 4 months after the beginning of the infection. Wong et al. [14] reported that IgE-ISAGA and IgE ELISA were positive in $63 \%$ and $100 \%$ of women who seroconverted during gestation, respectively. The decline of anti- $T$. gondii $\operatorname{IgE}$ in individual patients varied considerably; positive IgE-ISAGA and IgE ELISA tests were found in serum from one patient 37 weeks after seroconversion. In the present study, $\operatorname{IgE}$ antibodies detected by ISAGA were present in 26 $(84 \%)$ of 31 sera from patients with acute toxoplasmosis. However, positive IgE ISAGA tests were also found in sera from two patients with latent infection taken $>1$ year after the onset of the clinical symptoms of infection.

The AC/HS test is a differential agglutination procedure which compares the titres obtained with formalinfixed tachyzoites (HS antigen) with those obtained with acetone-fixed tachyzoites (AC antigen). The AC and HS antigens are membrane-associated antigens, the first found predominantly in tachyzoites and the latter in tachyzoites and bradyzoites [18]. The AC and HS antigen preparations contain antigens which are recognised by $\operatorname{IgG}$ antibodies. High titres in the $\mathrm{AC}$ test are associated with a recently acquired infection, whereas high titres in the HS test are associated with past infection [16, 18, 19]. Dannemann et al. [19] have shown that the $\mathrm{AC} / \mathrm{HS}$ test is useful for confirming acute toxoplasmosis in patients who have both IgM and IgG specific antibodies. In a group of 33 patients with recently acquired toxoplasmosis (19 pregnant women who acquired infections during the pregnancy and 14 non-pregnant patients with toxoplasmic lymphadenopathy), the AC/HS test correctly identified acute infection in all of the 19 pregnant patients and in 12 of the 14 cases of lymphadenopathy. On the other hand, an acute $\mathrm{AC} / \mathrm{HS}$ pattern was still observed in five of eight patients who were evaluated 14-21 months following the clinical onset of toxoplasmic lymphadenopathy and in 2 of 14 individuals who had been infected for $>2$ years. In the present study, 30 (97\%) of 31 patients with a recent $T$. gondii infection had an AC/HS pattern compatible with acute toxoplasmosis. On the other hand, an acute pattern in the AC/HS test was also detected in $15(45 \%)$ of 33 subjects with latent infection, including four subjects with significant levels of anti- $T$. gondii $\operatorname{IgM}$ antibodies detected by ELISA. 
In recent years, several immuno-enzymic assays for specific IgG have been adapted to estimate antibody avidity in certain infections, including toxoplasmosis [22-26, 36]. In solid-phase ELISA systems, a hydrogen bond-disrupting agent is commonly used to elute lowavidity antibodies from immobilised antigen. Among the hydrogen bond destabilisers, urea has been used extensively at concentrations of $6-8 \mathrm{M}$ [22-26, 3741]. Hedman et al. [22] reported an IgG avidity ELISA for toxoplasmosis based on titration of each serum sample and calculation of the titres, with and without urea treatment, in relation to a defined cut-off value. Avidity indices $<10 \%$ were found in sera from five patients with acute toxoplasmosis within 12 weeks of the onset of clinical symptoms. In contrast, in sera from 21 subjects with pre-existing immunity to $T$. gondii, the avidity indices ranged from 25 to $97 \%$ (mean index $=50.1 \%$ ). Jenum et al. [25] compared the results obtained with an avidity ELISA test based on the titration of sera using the Platelia Toxo-IgG kit in sera from pregnant women with different $T$. gondii immune states. The IgG avidity indices for 58 sera obtained within 20 weeks of the estimated time of infection from women diagnosed as having acute toxoplasmosis (seroconversion or a four-fold or greater rise in the Sabin-Feldman dye test titre) ranged from 0.1 to $26.5 \%$ (mean index $=4.9 \%$ ). In 26 sera from women with latent infection, the avidity indices ranged from 30.6 to $75.4 \%$ (mean index $=51.3 \%$ ).

An avidity test for toxoplasmosis using the Falcon assay screening test $\left(\right.$ FAST $^{\circledR}$ ) ELISA system based on the assay of a single serum dilution was described recently [26]. The avidity indices for 25 sera obtained 2 months after the onset of clinical symptoms from patients diagnosed as having acute toxoplasmosis (IgM antibodies detected by indirect immunofluorescence, IIF, and ELISA, plus either seroconversion or a fourfold or greater rise in the titre of $T$. gondii-specific IgG by IIF) ranged from 10 to $40 \%$ (mean index $=23.5 \%$ ), whereas for 25 sera from patients with pre-existing $T$. gondii immunity, the indices ranged from 58 to $94 \%$ (mean index $=73.1 \%$ ).

Variations in the ranges for low- and high-avidity antibodies are expected and are probably related to several factors, including patient heterogeneity, immune status at time of blood collection, time of blood sampling relative to infection onset, assay technique, antigen preparation, type and concentration of hydrogen bond-disrupting agent and method of calculating antibody avidity. The present study used two different tests to evaluate the avidity of $\operatorname{IgG}$ specific to $T$. gondii. One method was based on the titration of each serum sample and calculation of the titres, with and without urea treatment, in relation to a defined cut-off value $[22,25]$. In the other method, a single serum dilution was used and the absorbances of the reactions performed in the presence and absence of urea were compared $[24,26]$. The titration method was found to be more sensitive for diagnosing a recent primary $T$. gondii infection, as all 31 sera from patients with acute toxoplasmosis had avidity indices compatible with a recent infection. With the single dilution method, sera from four patients had equivocal results. In the 33 patients with latent infection, similar results were obtained with the two avidity methods; only one serum sample had an avidity value that was not compatible with the titration method.

The results of the present study show that the current serological markers used for diagnosing acute acquired toxoplasmosis have significant limitations. The data suggest that determination of the avidity of $T$. gondiispecific IgG by the titration method in patients with detectable IgM antibodies is the most efficient technique for defining the stage of infection with T. gondii.

\section{References}

1. Kean BH. Clinical toxoplasmosis - 50 years. Trans $R$ Soc Trop Med Hyg 1972; 66: 549-571.

2. Krick JA, Remington JS. Toxoplasmosis in the adult - an overview. N Engl J Med 1978; 298: 550-553.

3. Remington JS, Desmonts G. Toxoplasmosis. In: Remington JS, Klein JO (eds) Infectious diseases of the fetus and newborn infant. Philadelphia, WB Saunders Company. 1990: 89-195.

4. van Loon AM, van der Logt JTM, Heessen FWA, van der Veen J. Enzyme-linked immunosorbent assay that uses labeled antigen for detection of immunoglobulin $\mathrm{M}$ and $\mathrm{A}$ antibodies in toxoplasmosis: comparison with indirect immunofluorescence and double-sandwich enzyme-linked immunosorbent assay. J Clin Microbiol 1983; 17: 997-1004.

5. Brooks RG, McCabe RE, Remington JS. Role of serology in the diagnosis of toxoplasmic lymphadenopathy. Rev Infect Dis 1987; 9: 1055-1062.

6. Del Bono V, Canessa A, Bruzzi P, Fiorelli MA, Terragna A. Significance of specific immunoglobulin $\mathrm{M}$ in the chronological diagnosis of 38 cases of toxoplasmic lymphadenopathy. $J$ Clin Microbiol 1989; 27: 2133-2135.

7. Bobic B, Sibalic D, Djurkovic-Djakovic O. High levels of IgM antibodies specific for Toxoplasma gondii in pregnancy 12 years after primary Toxoplasma infection. Gynecol Obstet Invest 1991; 31: 182-184.

8. Bertozzi LC, Suzuki LA, Rossi CL. Serological diagnosis of toxoplasmosis: usefulness of $\operatorname{IgA}$ detection and $\operatorname{IgG}$ avidity determination in a patient with a persistent $\operatorname{IgM}$ antibody response to Toxoplasma gondii. Rev Inst Med Trop São Paulo 1999; 41: 175-177.

9. Le Fichoux Y, Marty P, Chan H. Les IgA sériques spécifiques dans le diagnostic de la toxoplasmose. [specific serum IgAs in the diagnosis of toxoplasmosis.] Ann Pédiatr (Paris) 1987; 34: 375-379.

10. Decoster A, Darcy F, Caron A, Capron A. IgA antibodies against P30 as markers of congenital and acute toxoplasmosis. Lancet 1988; 2: 1104-1107.

11. Pujol M, Morel C, Malbruny B. Intérêt de la recherche des $\operatorname{IgA}$ dans le diagnostic de la toxoplasmose. [Value of $\operatorname{IgA}$ detection in the diagnosis of toxoplasmosis.] Pathol Biol 1989; 37: 893-896.

12. Pinon JM, Toubas D, Marx C et al. Detection of specific immunoglobulin $\mathrm{E}$ in patients with toxoplasmosis. $J$ Clin Microbiol 1990; 28: 1739-1743.

13. Bessières $M H$, Roques $C$, Berrebi A, Barre V, Cazaux M, Séguéla JP. IgA antibody response during acquired and congenital toxoplasmosis. J Clin Pathol 1992; 45: 605-608.

14. Wong SY, Hajdu M-P, Ramirez R, Thulliez P, McLeod R, Remington JS. Role of specific immunoglobulin $\mathrm{E}$ in diagnosis of acute toxoplasma infection and toxoplasmosis. $J$ Clin Microbiol 1993; 31: 2952-2959.

15. Takahashi EEH, Rossi CL. Use of three immunological techniques for the detection of Toxoplasma spIgA antibodies in acute toxoplasmosis. J Clin Pathol 1994; 47: 1101-1104. 
16. Montoya JG, Remington JS. Studies on the serodiagnosis of toxoplasmic lymphadenitis. Clin Infect Dis 1995; 20: 781-789.

17. Thulliez P, Remington JS, Santoro F, Ovlaque G, Sharma S, Desmonts G. Une nouvelle réaction d'agglutination pour le diagnostic du stade évolutif de la toxoplasmose acquise. [A new agglutination reaction for the diagnosis of the developmental stage of acquired toxoplasmosis.] Pathol Biol 1986; 34: $173-177$.

18. Suzuki Y, Thulliez P, Desmonts G, Remington JS. Antigen(s) responsible for immunoglobulin $\mathrm{G}$ responses specific for the acute stage of Toxoplasma infection in humans. $J$ Clin Microbiol 1988; 26: 901-905.

19. Dannemann BR, Vaughan WC, Thulliez P, Remington JS Differential agglutination test for diagnosis of recently acquired infection with Toxoplasma gondii. J Clin Microbiol 1990; 28: 1928-1933.

20. Eisen HN, Siskind GW. Variations in affinities of antibodies during the immune response. Biochemistry 1964; 3: 996-1008.

21. Werblin TP, Kim YT, Quagliata F, Siskind GW. Studies on the control of antibody synthesis. III. Changes in heterogeneity of antibody affinity during the course of the immune response. Immunology 1973; 24: 477-492.

22. Hedman K, Lappalainen M, Seppälä I, Mäkelä O. Recent primary Toxoplasma infection indicated by a low avidity of specific IgG. J Infect Dis 1989; 159: 736-740.

23. Camargo ME, da Silva SM, Leser PG, Granato CH. Avidez de anticorpos IgG específicos como marcadores de infecção primária pelo Toxoplasma gondii. [Avidity of specific IgG antibodies as markers of recent primary infection caused by Toxoplasma gondii.] Rev Inst Med Trop São Paulo 1991; 33: 213-218

24. Holliman RE, Raymond R, Renton N, Johnson JD. The diagnosis of toxoplasmosis using IgG avidity. Epidemiol Infect 1994; 112: 399-408.

25. Jenum PA, Stray-Pedersen B, Gundersen A-G. Improved diagnosis of primary Toxoplasma gondii infection in early pregnancy by determination of antitoxoplasma imunoglobulin G avidity. J Clin Microbiol 1997; 35: 1972-1997.

26. Rossi CL. A simple, rapid enzyme-linked immunosorbent assay for evaluating immunologlobulin $\mathrm{G}$ antibody avidity in toxoplasmosis. Diagn Microbiol Infect Dis 1998; 30: 25-30.

27. Ashburn D, Joss AWL, Pennington TH, Ho-Yen DO. Do IgA, $\mathrm{IgE}$, and IgG avidity tests have any value in the diagnosis of toxoplasma infection in pregnancy? J Clin Pathol 1998; 51: $312-315$.

28. Liesenfeld O, Press C, Montoya JG et al. False-positive results in immunoglobulin $\mathrm{M}$ (IgM) Toxoplasma antibody tests and importance of confirmatory testing: the Platelia Toxo IgM test.
$J$ Clin Microbiol 1997; 35: 174-178.

29. Naot Y, Remington JS. An enzyme-linked immunosorbent assay for detection of IgM antibodies to Toxoplasma gondii: use for diagnosis of acute acquired toxoplasmosis. J Infect Dis 1980; 142: 757-766.

30. Partanen P, Turunen HJ, Paasivuo RTA, Leinikki PO. Immunoblot analysis of Toxoplasma gondii antigens by human immunoglobulins G, M, and A antibodies at different stages of infection. J Clin Microbiol 1984; 20: 133-135.

31. Huskinson J, Thulliez P, Remington JS. Toxoplasma antigens recognized by human immunoglobulin A antibodies. J Clin Microbiol 1990; 28: 2632-2636.

32. Turunen H, Vuorio KA, Leinikki PO. Determination of IgG, $\operatorname{IgM}$ and IgA antibody responses in human toxoplasmosis by enzyme-linked immunosorbent assay (ELISA). Scand $J$ Infect Dis 1983; 15: 307-311.

33. Gorgievski-Hrisoho M, Germann D, Matter L. Diagnostic implications of kinetics of immunoglobulin $\mathrm{M}$ and A antibody responses to Toxoplasma gondii. J Clin Microbiol 1996; 34: 1506-1511.

34. Takahashi EEH, Rossi CL. IgM and IgA antibody responses in 12 cases of human acquired toxoplasmosis. Rev Inst Med Trop São Paulo 1997; 39: 327-331.

35. Decoster A, Gontier P, Dehecq E, Demory JL, Duhamel M. Detection of anti-Toxoplasma immunoglobulin A antibodies by Platelia-Toxo IgA directed against P30 and by IMx Toxo IgA for diagnosis of acquired and congenital toxoplasmosis. J Clin Microbiol 1995; 33: 2206-2208.

36. Joynson DHM, Payne RA, Rawal BK. Potential role of IgG avidity for diagnosing toxoplasmosis. J Clin Pathol 1990; 43: $1032-1033$.

37. Hedman K, Seppala I. Recent rubella virus infection indicated by a low avidity of specific IgG. J Clin Immunol 1988; 8: 214-221.

38. Hedman K, Rousseau SA. Measurement of avidity of specific IgG for verification of recent primary rubella. J Med Virol 1989; 27: 288-292.

39. Blackburn NK, Besselaar TG, Shoub BD, O'Connell KF. Differentiation of primary cytomegalovirus infection from reactivation using the urea denaturation test for measuring antibody avidity. J Med Virol 1991; 33: 6-9.

40. Ward KN, Dhaliwal W, Ashworth KL, Clutterbuck EJ, Teo CG. Measurement of antibody avidity for hepatitis $\mathrm{C}$ virus distinguishes primary antibody responses from passively acquired antibody. J Med Virol 1994; 43: 367-372.

41. Gray JJ. Avidity of EBV VCA-specific antibodies: distinction between recent primary infection, past infection and reactivation. J Virol Methods 1995; 52: 95-104. 